\title{
Key success factors when implementing strategic manufacturing initiatives
}

\section{Enrique Minarro-Viseras, Tim Baines and Mike Sweeney}

\section{Introduction}

Manufacturing companies formulate strategies to develop their manufacturing capabilities and therefore to increase their competitiveness in the marketplace. The main emphasis in the strategic manufacturing literature has for many years been on the formulation side of strategies (Grundy, 1998; Al-Ghamdi, 1998). The issue of implementation has received less attention, although implementation of strategic initiatives has frequently been considered to be the graveyard of strategy (Grundy, 1998). Many companies are still facing major difficulties during the implementation of strategic decisions derived from the formulation of business, marketing or manufacturing strategies (Al-Ghamdi, 1998). As Grundy (1998) points out, strategic management should move from a 90:10 concern with strategy formulation relative to implementation to at least a 50:50 concern with each. Otherwise, no matter how good the strategic decisions are, companies would not benefit from them (Al-Ghamdi, 1998). This argument is reinforced by Beer et al. (1990) who attribute much of the shortcomings in the strategy area to failures in the implementation process rather than in the formulation of strategy itself. Unfortunately, once a strategy has been developed, its implementation appears to be seen as a matter of operational detail and tactical adjustment carried out within the boundaries of existing company's structures and procedures (Pellegrinelli and Bowman, 1994). Over the last few years there has been increasing interest in the research of new methods to improve the efficiency of strategy implementation. Project management has received much of this interest. Authors such as Van Der Merwe (2002) have argued that strategies do not fail when they are being analysed or when the objectives are being set but during implementation and, more particularly, due to the lack of proper project management. Project management is gaining in popularity as a vehicle for the implementation of business and marketing strategies. Increasingly, project management is being applied outsides its core domain. Strategic manufacturing literature is lagging behind in the research and development of project management as a vehicle for the implementation of formulated manufacturing strategies.

This paper contributes to the literature on implementation of manufacturing strategies by identifying the key success factors (KSFs) in the project management of the implementation of strategic manufacturing initiatives (SMIs). It describes a survey of practitioners internationally. The paper presents the research methodology and the findings from the survey. This study is part of a larger research programme that aims to develop a methodology that provides a consistent step by step discipline for implementing SMIs and includes the tools, templates and techniques that reflect the distinctive nature of project management within the strategic manufacturing implementation area.

The results of our survey suggest that in the manufacturing environment the project manager of SMI implementation projects assumes a high responsibility for the overall success. This is reinforced by top or senior management commitment to the project and the clear and early communication of the project evaluation measures to the project team members. In general the project manager's personal qualities included in the list of KSFs and his understanding of the strategic direction of the manufacturing function and of the organisation play a critical role that must not be overlooked.

The paper is structured as follows. First, some key literature and issues surrounding the formulation of a manufacturing strategy and the challenge of implementation are presented together with the use of project management as a vehicle for strategy implementation. After introducing the specific research methodology to identify the KSFs, the design of the questionnaire and the survey's results are described. Finally, the key findings are presented, and suggestions made for further research. 


\section{Background: manufacturing strategy implementation}

In the past, manufacturing strategy has been a neglected topic of discussion. The manufacturing function was regarded merely as a collection of resources and constraints. It was expected to fulfil, as efficiently as possible, the production targets generated by the marketing strategy within the capacity and capital expenditure constraints imposed by the financial strategy (Skinner, 1969). Skinner was the first to observe that a company's manufacturing function could do more than simply produce and ship the products. Since Skinner's (1969) article, "Manufacturing missing link in corporate strategy", one of the reasons for the loss of a competitive edge by western manufacturing businesses became increasingly apparent. Manufacturing had long been regarded as the poor man of the company functional hierarchy. It was perceived as dirty, noisy, and the realm of the technicians. In consequence, senior management avoided involvement in manufacturing, decisions were taken on a tactical basis by specialists who were not necessarily aware of overall corporate strategy, and instead of being a valuable asset and a tool of corporate strategy, manufacturing became a liability (Skinner, 1969). As Fillipini and Raffo (1990) point out, this approach was adequate in the supply-driven economic climates of the industrialised countries after World War II, when customers were not too discerning. Whilst the financiers and marketing people concentrated on sorting out corporate strategy, the task of the manufacturing function was simply to meet the required quantities and schedules, with a minimum of cost variance (Fillipini and Raffo, 1990).

Skinner identified the absence of manufacturing in the corporate strategic planning process. The need for a manufacturing strategy was established because manufacturing strategy can be used to exploit certain properties of the manufacturing function to achieve competitive advantage (Skinner, 1969). Hayes and Wheelwright (1984) define manufacturing strategy as the deployment and development of manufacturing capabilities in total alignment with the firm's goals and strategies. Platts (1990) defines manufacturing strategy as a pattern of decisions, both structural and infrastructural, which determine the capability of a manufacturing system and specify how it will operate in order to meet a set of manufacturing objectives which are consistent with overall business objectives.

The mechanism needed to choose the content of a strategy is a strategy design process (Baines et al., 1993). Manufacturing companies use strategy design processes to select the many changes in their organizations necessary to survive and prosper as successful competitors in the future (Gunn, 1987). The formulation of a manufacturing strategy must be one of the key tasks for operations managers (Platts, 1990). Many manufacturing strategy formulation processes exist in literature (for example, Gunn, 1987; Miller, 1988; Platts, 1990; DTI, 1988).

The problem is that formulating a manufacturing strategy is far from enough to achieve the desired benefits. Marucheck et al. (1990) carried out an exploratory empirical study where executives from a cross-sectional representation of leading-edge firms indicated that the real benefits of a manufacturing strategy come from implementation as opposed to the formulation side of the strategy.

The formulations of manufacturing strategies (DTI, 1988) result in the identification of a set of desired manufacturing capabilities or manufacturing strategy content, and a list of SMIs. The sequential or parallel implementation of SMIs move the manufacturing function towards the contents of the manufacturing strategy formulated. SMIs are intended as implementation steps to acquire the strategic manufacturing capabilities chosen. The implementation of a manufacturing strategy involves the management and execution of SMIs. The notion of fit between the content of a manufacturing strategy and SMIs is built on the "internal consistency" argument which asserts that a functionally motivated step that seems to have merit when viewed alone may lead to poor results because of its mismatch with the manufacturing strategy orientation (Kotha and Swamidass, 2000). Figure 1 has been created to graphically represent the fit between the concepts of manufacturing strategy, SMI, and the implementation of SMIs.

A SMI can be defined as a major manufacturing effort that will have a sizeable strategic impact on the manufacturing capabilities: the manufacturing external competitive edge, its internal capabilities or its financial performance - or all three. Garvin (1993) defines a SMI as "a major manufacturing effort that seeks improvement over a specified time period. It includes both quantitative goals and specific milestones; equally important, it can be applied to the entire 
manufacturing organisation". For these initiatives to be achieved they must at some stage be translated into an operational implementation plan that needs to be successfully and rigorously managed. The exploratory study carried out by Marucheck et al. (1990) indicates that manufacturing strategy implementation is a project-oriented task where the implementation plan is comprised of a hierarchy of projects. Individuals in charge of the implementation of SMI projects struggle to find an appropriate methodology that contributes to their knowledge or capability to successfully and rigorously implement the SMIs proposed. White and Fortune (2002) conducted an empirical study designed to capture the "real world" experiences of people active in project management. Their research consisted of a survey sent to 995 project managers from a wide range of industries and organisations with 236 responses ( 23.72 per cent response rate). Two of the main findings of their study are as follows:

1. per cent (66) of respondents did not use any project management methodology; and

2. per cent (128) of respondents used their own "in house" project management methodology.

White and Fortune's (2002) results show that the current project management methodologies available in the literature are not found useful by a large proportion of practitioners in the field in which they operate. Whereas practitioners need efficient methods of managing the successful and rigorous implementation of strategies in their business sector, a project-oriented approach has been identified as a more efficient process to manage the implementation of strategic changes. More and more companies are beginning to understand the benefits that can be derived from using project management tools and methodologies to help drive planned change (Clarke, 1999). Many authors and case studies, for example Hauc and Kovac (2000), have demonstrated that project management ensures a high level of efficiency in the implementation of set objectives in general. Grundy (1998) and Pellegrinelli and Bowman (1994) have given interesting views on the integration of strategic business implementation and project management. Marketing literature also suggests some kind of project management approach for the implementation of strategies, "identifying and prioritising activities, deploying resources, and coordinating and directing actions" (Sashittal and Wilemon, 1996).

The other area of research requiring further investigation is change management. In an attempt to use change management concepts as a vehicle for the implementation of SMIs, they seem to be inappropriate. Change management literature deals with changes in the culture, structure and processes that will improve the performance and competitiveness of a company. The literature is overwhelmed with different management initiatives for managing process changes in organisations (Grover et al., 1995; Zairi and Sinclair, 1995; O'Neill and Sohal, 1999). Generally the application of a change management model such as Business Process Benchmarking, Process Redesign or Business Process Reengineering would result in the identification of initiatives that, if successfully implemented, would drive a performance and competitiveness transformation in a company. The implementation of such a set of strategic initiatives, whether part of the change management model or not, has to be successfully managed and implemented. In this context, project management concepts and techniques have been identified as a more efficient process to manage the implementation of strategic initiatives (Clarke, 1999).

Most authors state that project management had its origin in 1958 with the development of the PERT methodology (Van Der Merwe, 2002). This approach was based on the computational planning and control models originating in large projects, aerospace, defence and construction (Maylor, 2001). In the American Project Management Institute's publication, A Guide to the Project Management Body of Knowledge (PMI Standards Committee, 2000), a project is defined as "a temporary endeavour undertaken to create a unique product or service" (PMI Standards Committee, 2000) and project management is defined as "the application of knowledge, skills, tools and techniques to project activities to meet project requirements" (PMI Standards Committee, 2000). These concepts and the whole structure and content of generic project management methodologies such as PMI Standards Committee (2000) and APM Association for Project Management (2000) seem adequate for projects dealing with construction and high technology activities. For project management to be effective in implementing strategy, the structure and content of the project management methodology needs to be consistent with the field in which it is utilised. The traditional approach to project management gives very limited treatment to many relevant issues in the context in which 
project managers (regardless of whether they have that title) operate today in many industries including the strategic manufacturing area (Maylor, 2001). According to Turner (1993) the present knowledge base of project management relies on large capital construction projects that represent only 10 per cent of the projects. Authors such as Maylor (2001) have argued that the project management knowledge base at present is too wide and poorly structured. As a result the literature is confusing for practitioners. Maylor (2001) also argues that there is even some doubt as to whether the traditional methods are effective in many sectors. With the change in the nature of project management to cover a wider range of activities comes the need to re-invent the bodies of knowledge, which are heavily influenced by the "traditional projects" sector (Maylor, 2001). Large areas of the project management bodies of knowledge, primarily PMI Standards Committee (2000) and APM Association for Project Management (2000), are discounted by organisations as being too cumbersome or simply inappropriate (Maylor, 2003). At this level the implementation of strategic manufacturing projects often calls for a different structure and mix of tools and techniques to traditional project management. Benefit would be gained from some attempt to represent project management in a more integrative and contingent manner in the strategic manufacturing area.

In order to develop a methodology that would successfully guide practitioners in the implementation of SMIs, we must focus on those tasks and activities that have to be done well in order to achieve success. Success is however more likely by focusing attention on the important few key factors and by separating them out from the many trivial ones (Clarke, 1999). KSFs can be thought of as the tasks or attributes that should receive priority attention because they strongly drive performance. KSFs must go right to ensure that goals or objectives are met. Once these factors have been identified, the value of benchmarking project management methodologies then comes from drawing attention to those tasks that are key to the success of SMI implementation projects (Clarke and Garside, 1997).

\section{Research design}

\section{Research aim and methodology}

The purpose of the research is to identify the critical factors in the project management of the implementation of SMIs. The literature does not provide these critical factors. Therefore, it is necessary to seek practitioners' judgement to identify the most critical aspects that positively influence the successful implementation of SMIs. Therefore in order to gain a thorough understanding of these factors it is important to gather the experience and knowledge of many industries, from different geographic locations, in a broad range of types and sizes of SMIs. The nature of this research meant that a questionnaire-based survey of practitioners worldwide was selected as the most appropriate research method among those available. Other methods include personal interviews or case studies. The chosen method facilitates the gathering of the required information from a large sample size over a wide geographic area. It also eliminates the possibility of interviewer bias. The main disadvantage is the inability to ask respondents for more detailed information.

The principal components of the research methodology are illustrated in Figure 2 and include: define research categories, literature search to identify KSFs, design and validation of the questionnaire, selection of manufacturing organisations, execution of survey and analysis of the results.

\section{Define research categories}

Research categories were needed to provide a basic structure and set of key issues around which the literature search and the questionnaire could be formed. Based on the studies carried out by Mikkelsen et al. (1991) in management of internal projects, Marucheck et al. (1990) in manufacturing strategy process in practice, and AlGhamdi (1998) in obstacles to successful implementation of strategic decisions, and a review of the project management body of knowledge, primarily PMI Standards Committee (2000) and APM Association for Project Management (2000), the three areas of research were identified as people, organisation and systems.

The area of people deals with the individuals and groups involved or affected by the strategic implementation, the area of organisation deals with the strategic link and company-wide related issues surrounding the SMI 
implementation project, whilst systems deals with the project management processes used in the implementation. These areas have been subdivided into individual elements for research.

A survey of the literature suggests four elements of study in the people category: project manager (or SMI implementation leader); top/senior management (project sponsors or clients); project team members; and manufacturing employees (non project team members but affected by the project). The category of organisation is dealt with in literature around two elements: strategic link and company-wide; social and external influences. The systems category is formed by one element dealing with project management processes: project management processes.

For each of these elements, the question of "which factors related to each are critical to the success of the implementation of a SMI" need to be addressed.

\section{Literature search to identify potential KSFs}

The literature search was focused on a critical review of publications in general project management, project management as a vehicle for strategy implementation, change management and key organisational context factors. A total of 106 factors were identified that have been included in the questionnaire from more than 20 papers. The list of authors includes El-Sabaa (2001), Marucheck et al. (1990), Milis and Mercken (2002), Al-Ghamdi (1998), Clarke (1999), Hartman and Ashrafi (2002), and Umble et al. (2003). The list of these factors and the relevant literature that suggests them are shown in the Appendix.

\section{Design and validation of the questionnaire}

The structure of the questionnaire was based on the research categories identified. An electronic questionnaire was produced, with an explanation at the beginning followed by seven sections of questions corresponding to the seven research elements. Authors dealing with empirical methodologies emphasise the importance of pre-testing and refinement of survey instruments (Hunt et al., 1982; Baker, 1991; Webb, 1992). The pre-test of the survey considers two separate issues, the content and the face validity. These two dimensions were addressed.

First, content validity refers to how adequately the contents of the questionnaire reflects the body of knowledge in the subject. The questions included in the questionnaire were constructed from a review of relevant literature in general project management, project management as a vehicle for strategy implementation, change management, as well as on key organisational context factors, which resulted in the generation of an holistic set of potential KSFs in the implementation of SMIs for testing. Primarily opinions were sought from known groups (Green et al., 1988) in the academic and industrial fields who could contribute expert opinions and knowledge about the content validity of the questionnaire using an interview approach. Content validity was piloted using two university instructors and then piloted again using four managers selected from a British manufacturing company. The interviews conducted were designed around an open-ended discussion ensure potential content validity problems would not be encountered at a later phase of the study. A few revisions were required: Minor rewordings to questions to remove ambiguities, reduction in the number of questions from 176 to 106 through consolidation, and slight changes to the layout of the questionnaire to improve readability. The classification of factors into seven categories was found appropriate. The classification was also found useful to improve readability, flow and understanding of the questionnaire. This classification also facilitated the analysis of data and discussion of the results.

Second, face validity testing considers whether or not the scales appear to be applicable and satisfactory to the respondents (Cronbach, 1970). To conduct the face validity tests, the understanding, interpretation and comprehension of questions by subjects were evaluated. This was combined with an appraisal of respondents' willingness and ability to respond to the questionnaire. Face validity was tested using two university instructors and then piloted again using four managers selected from a British manufacturing company. Most university instructors and industry managers expressed the view that a bigger scale was necessary to reflect the small differences in levels of feeling and attitude to the questions. The scale initially used in the questionnaire was based on the seven-point Likert $(1932,1967)$ scoring system. The Likert scale was used because it effectively measures the level of feeling and 
attitude to the question, it is relatively easy to construct and administer, and the respondents find them easy to answer due to response categories allowing an expression of the intensity of their attitude (Malhotra, 1993). Scales with fewer that five points limit the respondent's ability to discriminate because of the inability to estimate detailed graduations of opinion (Boote, 1981). As a result of the pre-test of the questionnaire it was decided to increase the range of the scale to nine points. This change was accepted as it would increase the reliability and validity of the responses (Churchill and Peter, 1984).

\section{Selection of manufacturing organisations}

The factors influencing the success of SMI implementation projects could possibly vary based on the specific characteristics of a company, such as the manufacturing sector and company's location. Other variations could be due to the characteristics of the SMI, such as the type of SMI considered and the size of the project in terms of number of people affected in the implementation process or by its outcome. Therefore, the selection of manufacturing organisations was carried out in order to provide a substantial diversity of products, organisation size, and geographic location. A sample of 135 manufacturing organisations were selected from across the globe, with responses being received from a cross-section of organisational sizes (Figure 3 ).

The industrial activities represented by the responding organisations are diverse and include tool manufacturing, refrigeration, power supply manufacturing, electronic assembly, motor manufacturing, thermostat manufacturing, appliance control manufacturing, shelving manufacturing, air conditioning, construction materials, metal fabrication, computer assembly, compressor manufacturing, general storage products, measuring devices, computer manufacturing, hand tool manufacturing, natural gas and propane products, telecom manufacturing, treatment and manufacturing of liquids, retail supply, home appliances manufacturing, cable assembly, microwave technology products, mobile power and charging systems, and vacuum systems manufacturing. The sample of organisations was selected from a database of high technology manufacturers within a multinational corporation. This corporation plays a small role in the operational activities of the companies. Besides the links, any similarities among these manufacturing companies are very limited. Therefore at this stage of the design of the research we argue that the companies in our study perform their activities with a great amount of independence and the findings resulting from our survey would be valid in the strategic manufacturing area.

\section{Execution of survey}

The questionnaire was mailed electronically during June 2003. The director of operations, the manufacturing manager, a functional manager, an engineer, or other employee within the manufacturing organisation were selected from each company to complete the questionnaire. The response rate was 78.5 per cent with 106 out of 135 organisations returning completed questionnaires for analysis. E-mail was chosen because many electronic surveys in the literature have obtained higher response rates compared to other paper based studies. Electronic questionnaires have other advantages over paper-based questionnaires. These include shorter analysis time, because they are received in electronic format, and less chances of errors made by the researcher when retyping the responses into a computer for further analysis.

\section{Results and interpretation of survey}

All questions related to KSFs included in the main body of the questionnaire were designed to accommodate the analysis of quantitative data. The respondents were asked to evaluate the extent to which 106 selected factors were actually critical for the success of SMI implementation projects. Each factor had a score range from 1 to 9 where the higher the number the higher the criticality. The wide range of possible scores, from 1 to 9 , was selected in order to capture accurately the degree of criticality that each respondent gives to each one of the factors. This had already been identified as important in the validation of the questionnaire.

A number of descriptive statistical techniques were applied to data generated in the survey in order to gain an insight into how each question was answered. Analysis techniques that were applied include mean, median, mode, standard deviation, variance, range, kurtosis, skewness and correlation analysis. Correlation analysis is used to 
measure linear relationships between two sets of variables and provides a measure of the strength of this relationship (Boyd et al., 1989), and so helps to decide whether it is appropriate to proceed with further analysis through data reduction techniques. Correlation analysis produces a correlation coefficient ( $r$ ). If the bivariate relationship is a perfect positive correlation $r=+1.00$; if it is a perfect negative correlation $r=-1.00$, and, if found not to exist (in linear form) $r=0.00$ (Baggaley, 1964). Literature suggests that correlation coefficients where values are higher than 0.7 or lower than -0.7 can be considered as strong relationships (Fitz-Gibbon and Morris, 1987; Weisberg and Bowen, 1977). The correlation coefficient analysis performed in this study shows that, with regard to negative correlation coefficients, the minimum value equals -0.24 . We conclude that there is no evidence of negative correlation between the factors in the questionnaire. The positive correlation coefficient analysis shows that only three pairs of factors have a coefficient higher than $0.7(0.82,0.74,0.72)$. Further analysis of the correlation of these three pairs of factors shows that there is no association between the factors and therefore, we conclude that there is no evidence of positive correlation between the factors in the questionnaire. Therefore, factor analysis was disregarded because applying factor analysis to a correlation matrix with only low correlations will require the solution of nearly as many principal components as there are original variables. The identification of KSFs in the implementation of SMIs has been based on frequency analysis and median analysis.

In order to identify the KSFs in the implementation of SMIs we must pay attention to those factors that have been identified as critical by the majority of practitioners and, which therefore, would be critical for the majority of types of SMIs and the contexts in which they are implemented. Based on the frequency distribution the categorical analysis, in a scale of 1 to 9 has been determined as having a top 20 per cent score, i.e. scores of 8 or 9 . KSFs are therefore, those factors that have received a score of 8 or 9 by more than 50 per cent of the 106 respondents, i.e. more than 53. Based on median analysis, KSFs would be those with a median higher than 8 . Results are presented in Table I.

The first column, named Pos., shows the order of criticality of the KSFs. The lower the number, the higher the criticality. The second column shows the research element referred by the KSF. The third column presents the KSFs. The fourth column shows the percentage and the absolute number (in brackets) of respondents scoring 8 or 9 against each factor. We have identified a total of $36 \mathrm{KSFs}$.

As well as evaluating the various factors, each respondent was asked to briefly describe a SMI that had been executed by the participating company and in which they have been involved to some degree. Table II shows the main types of initiatives that were considered.

The respondents were also asked for the number of people that were affected by the implementation of their chosen SMI (Figure 4). It shows a wide range of project sizes in the responding organisations.

\section{Analysis of the results}

The wide applicability in the strategic manufacturing area of the KSFs identified through this survey is supported by two main factors:

1. the wide range of areas covered by the SMIs as identified by the respondents;

2. the number of people affected by the SMIs used as a measure of the different project sizes.

We have identified a total of $36 \mathrm{KSFs}$. These factors have been grouped around the research categories for further analysis. They are presented in Table III.

Four relevant studies from the literature have been selected in order to be compared with the findings of this research. The KSFs from the selected literature are presented in Table IV, and identify KSFs in the following areas:

- Implementation of strategic decisions (Al-Ghamdi, 1998). The purpose of this study is to identify the key issues for smooth implementation of strategic decisions in British companies. The research was carried out through 100 questionnaires mailed to business companies with 27 questionnaires returned. 
- Effectiveness of project management (Clarke, 1999). This paper shows how by focusing in a number of KSFs the effectiveness of project management for managing change can be improved. This study is based on observations from an aerospace company.

- Implementation of IT software projects (Hartman and Ashrafi, 2002). This paper presents results of a survey of 36 software owners/sponsors, contractors/suppliers, and consultants on 12 projects. The empirical results address the success factors in IT projects.

- Implementation of an Enterprise Resource Planning (ERP) system (Umble et al., 2003). This article identifies success factors critical to a successful implementation of ERP systems. This research was carried out from a review of relevant literature and case study research.

\section{Analysis of the people category}

The highest number of KSFs is found under the project manager element of the people category. The results of our study demonstrate the critical importance of recruiting the right individual who is able to positively influence the ultimate success of the SMI implementation project. The success of SMI implementation projects is very much dependant on the project manager in charge of it. The results also show that in a manufacturing environment the successful implementation of SMI projects require full, continuous and visible support from the senior management. Senior management must be behind the project, the project manager and the project team and everyone in the organisation should be aware of that. There should be a clear and shared understanding of the project evaluation measures so that team members know how they are going to be evaluated. This will provide the right focus to their actions. Based on the critical success factors identified, the project manager can more efficiently select the project team members if the opportunity is given. The personal qualities and attitude of the project team members selected are key to creating the most suitable environment for the success of the project. The appropriate departmental reorganisations that will affect project team members must be created and communicated, so avoiding any dangerous misunderstandings and consequential lack of responsibility and ownership. Manufacturing employees' understanding of the SMI project, its progress and current status, and their knowledge about how to make use of the new initiative is critical for the successful implementation of the project as well as for the realisation of the benefits of the initiative and, therefore, the ultimate success of the project. The lowest scores for criticality in this research category are given by practitioners to project management training for project team members, senior management and manufacturing employees. In the project manager element of the questionnaire, the lowest criticality is given to the project manager's skills in finance and accounting, and project manager's experience with similar projects:

Finding 1. A project manager's individual qualities and skills are the most critical factor for the success of the implementation of a SMI.

Unexpectedly, the first and most important finding of our research is not emphasized by any of the four studies from literature presented in Table IV. This result highlights the distinctive nature of project management in the manufacturing area and, more specifically, in the implementation of strategic initiatives:

Finding 2. The success of project management in the strategic manufacturing field is very much dependent on the human side of a project.

The people category has received the highest criticality scores in our survey and, therefore, it should receive the maximum attention in the process of strategy implementation and in the design of a SMI implementation methodology.

\section{Analysis of the organisation category}

In the organisation category, the dedicated focus and full attention of the organisation on the SMI implementation project are critical factors for success. These are achieved by providing sufficient resources at the disposal of the project manager and team, limiting the number of projects being implemented the same time, linking all performance measures to Strategic Manufacturing objectives, and keeping project duration as short as possible. Again clarity and understanding appear to be critical factors in the form of having key implementation tasks and 
milestones sufficiently defined. The creation of a sense of urgency about the project seems to have important implications for the ultimate success of the SMI implementation project. Probably this sense of urgency may help to gain the required resources and additional funding, when needed, and to encourage people to spend the necessary time and effort to make things happen. Finally the manufacturing organisation must engage in excellent project management by formalising and continuously improving the processes involved in project implementation management and business change management. In the Social and External influences area, the key consideration should be given to creating a positive environment and good expectations for the future after the project has concluded, this will critically help the success of the implementation:

Finding 3. Organisations facing the successful accomplishment of a SMI must focus their efforts in ensuring the availability of resources and convincing employees of the criticality of the initiative.

Finding 4. Project management critically contributes to the success of the implementation of SMIs.

\section{Analysis of the systems category}

The American Project Management Institute (PMI Standards Committee, 2000) divide the project management processes into nine categories: project integration management, project scope management, project time management, project cost management, project quality management, project human resource management, project communications management, project risk management, and project procurement management. The results of our study show that, in the systems category, those processes that facilitate the achievement of the requirements of the project, its completion on time and within budget, are considered most important for the success of SMI implementation projects. The PMI Standards Committee (2000) defines these processes as follows: project quality management are the "processes required to ensure that the project will satisfy the needs for which it was undertaken" (PMI Standards Committee, 2000); project time management are the "processes required to ensure timely completion of the project" (PMI Standards Committee, 2000); project cost management are the "processes required to ensure that the project is completed within the approved budget" (PMI Standards Committee, 2000).

Surprisingly project risk management has received a very low criticality score. Risk management processes are not identified as critical by practitioners in the manufacturing area. Contrastingly, authors such as Cooke-Davies (2002) in his empirical research from more than 70 companies on KSFs in project management, identify the adequacy of company-wide education on the concepts of risk management, the maturity of an organisation's processes for assigning ownership of risks, the adequacy with which a visible risk register is maintained, and the adequacy of an up-to-date risk management plan as some of the most critical factors in project management success:

Finding 5. A successful project management methodology for the implementation of SMls would emphasise the use of project quality, cost and time management processes.

\section{Discussion}

\section{Research design}

The objective of the research design was to seek practitioners' judgement to identify the KSFs in the implementation of SMIs in practice. Kinnear and Taylor (1996) observed that when the information needs of a study require data about respondents' attitudes, perceptions, motivations, knowledge, and intended behaviour, asking people questions is essential. A respondent based information generation research method was chosen. The survey questionnaire approach was very useful for contacting a large number of people and to get their views. This method did not allow interviewer intervention to correct misunderstandings or to offer explanation and therefore, if a respondent was not clear about a question, little could be done to clarify this because no interviewer was available. These issues had been identified in previous research studies, for example Oppenheim (1996) and Zikmund (1997). Advantages of using a survey questionnaire included reliability in assuring respondent anonymity, reasonably low level of administration, high level of standardisation, reduced effects of bias introduced by interviewers, and the requirement of reduced resources. 
The research design consisted of five stages: definition of research categories and literature search to identify potential KSFs; design and validation of the questionnaire; selection of manufacturing organisations; execution of survey; and finally, analysis of the results. The first stage of the research received the most careful consideration. The content of the questionnaire had to be based on a rigorous literature search. The identification of research categories was needed to provide a basic structure and set of key issues around which the literature search and the questionnaire could be formed. A project management approach had been identified as the most appropriate approach for the implementation of SMIs. Therefore, a review of the project management bodies of knowledge, primarily PMI Standards Committee (2000) and APM Association for Project Management (2000), in addition to other relevant studies by Mikkelsen et al. (1991) in management of internal projects, Marucheck et al. (1990) in manufacturing strategy process in practice, and Al-Ghamdi (1998) in obstacles to successful implementation of strategic decisions, resulted in the identification of three research categories: people, organisation and systems. From these, an exhaustive literature search in publications in general project management, project management as a vehicle for strategy implementation, change management and key organisational context factors was carried out. Most of the literature did not report KSFs explicitly. A thorough understanding of the studies was required to identify potential KSF to be included in the questionnaire. These factors were classified according to the three research categories. A second purpose of the research categories was to provide a structure for the analysis of the results.

The research design, the selection of research categories, the literature review and the content of the questionnaire performed in this study have been influenced by a project management approach identified in the background to our research. This may have limited the respondents' choice and structure of factors for scoring. Further research could test the validity of the findings of this research by seeking practitioners' judgement using a different research method and a different research design.

\section{Results and analysis}

It was expected that this research would result in the identification of those tasks and activities that must be done well in order to succeed in the implementation of a SMI in practice. The choice of factors provided in the questionnaire for practitioners' evaluation of their criticality has been based on selected studies already reporting their importance in different contexts or fields. This study has then provided the degree and order of criticality of these factors in the strategic manufacturing implementation area. Additionally, in order to identify a widely applicable list of KSFs, we have defined a KSF as that factor that has received a top 20 per cent criticality score (i.e. scores of 8 or 9 ) by more than 50 per cent of the respondents. This list would form the basis for the development of a methodology that would guide practitioners in the successful and rigorous implementation of SMIs.

The main limitation identified in the research was the selection of organisations. The degree of influence of the existence of a corporation that owns all the companies in our study has been considered. Based on the independence in which the companies perform their diverse operational activities it has been concluded that the results presented should be applicable to other manufacturing organisations. Future studies using a different sample of companies will have to be carried out in order to confirm the universality of our results. Additionally, it could be argued that due to the wide variety of manufacturing organisations from different industries included in our study, the KSFs identified may not always be applicable to a specific manufacturing sector. Future research should study individual manufacturing sectors in order to report any alterations in the order of criticality of the factors.

\section{Conclusions and recommendations for further research}

\section{Conclusion}

The survey set out to determine the KSFs in the implementation of SMIs. In the manufacturing environment the project manager of SMI implementation projects assumes a high responsibility for the overall success. Special attention should be given to the project manager's personal qualities and skills included in the list of KSFs, and his understanding of the strategic direction of the manufacturing function and of the organisation. SMI implementation success comes more critically from the human or people side of project management as opposed to organisation 
and systems related factors. Other key findings include the organisation's focus on the resources available for the project, a shared understanding of the importance of the successful achievement of the initiative, the use of project management systems and more specifically the use of quality, cost, and time management processes.

Managing the implementation of manufacturing strategies and SMIs should be a subject of increased study. The strategic manufacturing community can learn from further research into the application of project management in business and marketing strategy implementation. A rigorous SMI project management implementation methodology focused on the KSFs identified by practitioners could be formed. Practitioners that follow this guide would increase the odds of success of the process of SMI implementation in their organisations. Benefits from the successful implementation of a selection of SMIs come from having moved manufacturing into the direction set out by the manufacturing strategy formulated.

\section{Future research}

Three future research initiatives have been identified in the discussions of the research design, and the results and analysis. First, future research could test the validity of the findings of this research by seeking practitioners' judgement using a different research method and a different research design. Second, future studies could use a different sample of companies in order to confirm the universality of our results. Thirdly, future research could study individual manufacturing sectors in order to report any alterations in the order of criticality of the factors.

Future work progressing on the findings presented should aim towards the development of a methodology that would guide manufacturing practitioners in the successful and rigorous implementation of SMIs. This work should involve the benchmark of practices and processes presented in literature against the KSFs identified. Finally a methodology could be formed, tested, refined and documented as a handbook for wider dissemination.

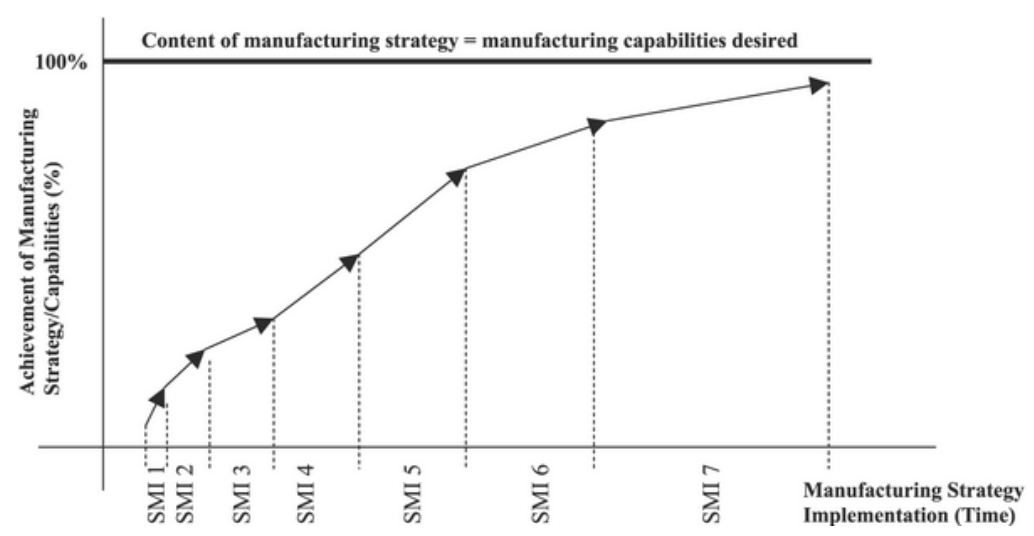

Figure 1 Implementation of a manufacturing strategy

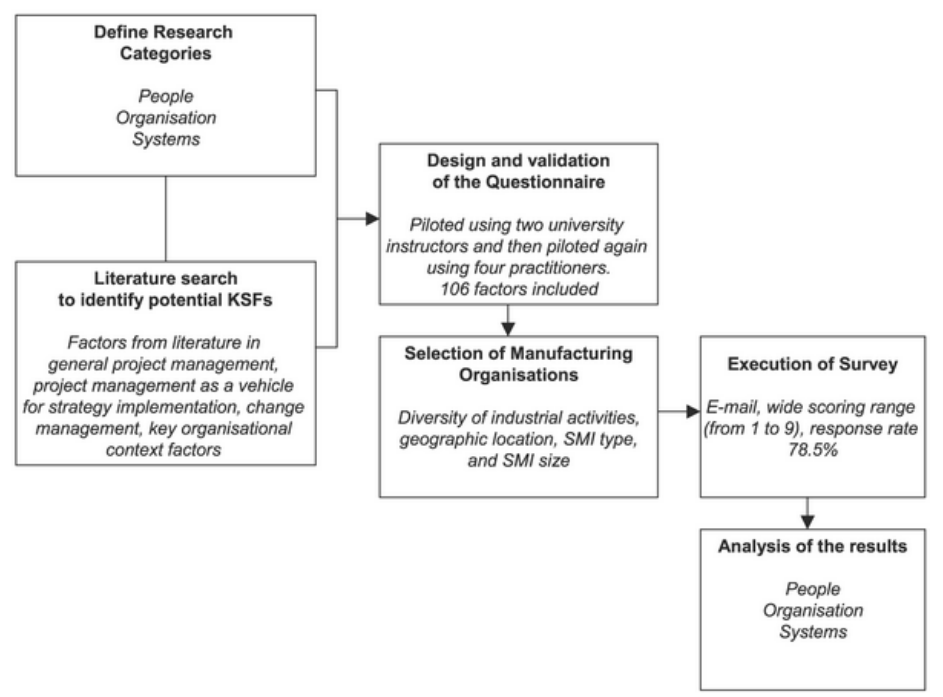




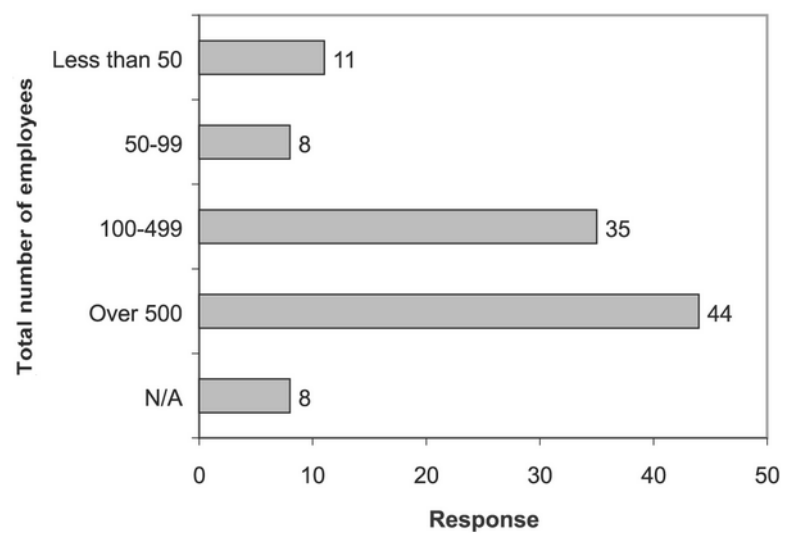

Figure 3 Total number of employees in the responding organisations

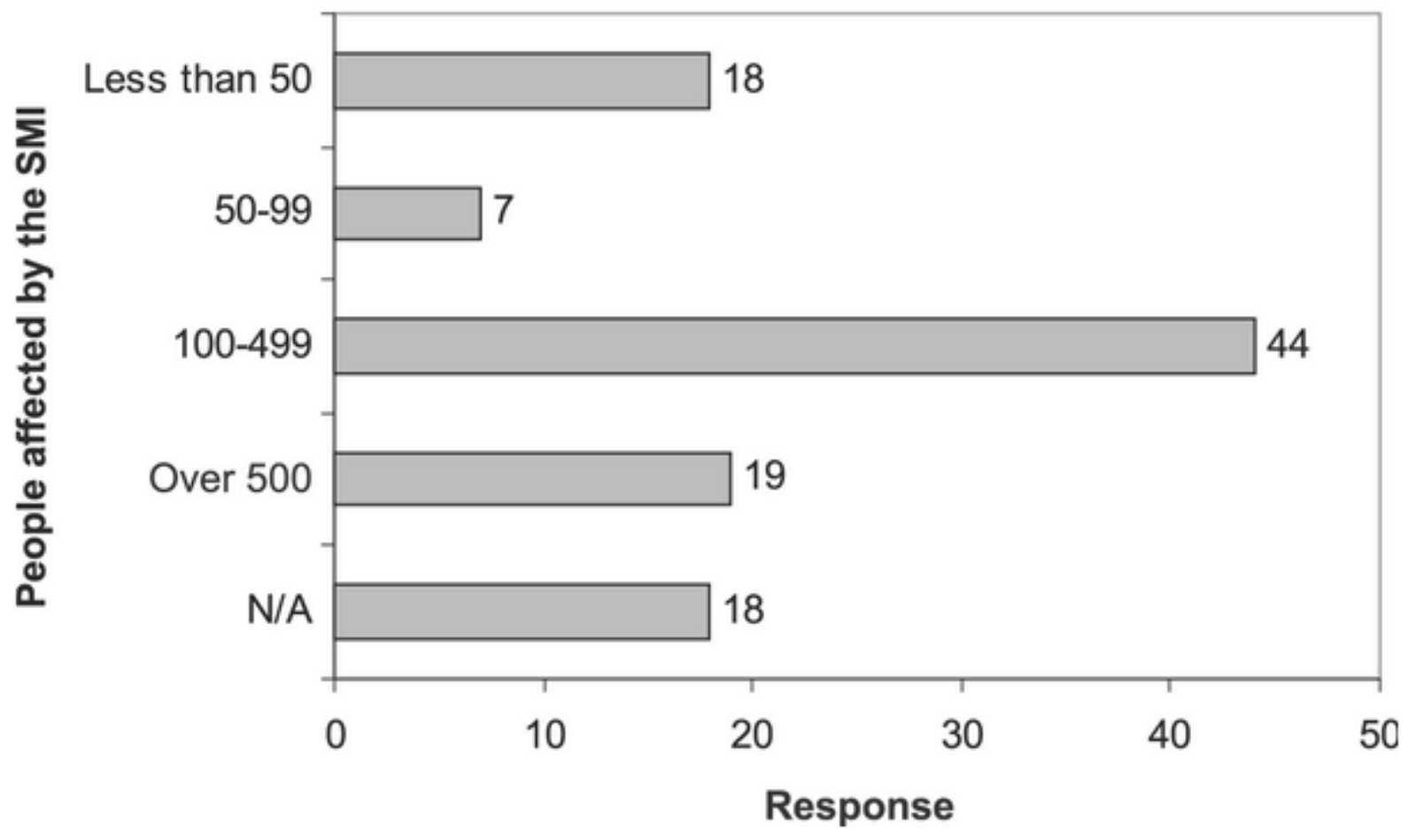

Figure 4 Number of people affected by the SMI chosen 


\begin{tabular}{|c|c|c|c|}
\hline Pos. & Research elements & KSFs & $\begin{array}{l}\text { Respondents } \\
\text { scoring } 8 / 9\end{array}$ \\
\hline 1 & Project manager & $\begin{array}{l}\text { Communication: project manager is able to listen, } \\
\text { understand, and communicate accurately and } \\
\text { constantly }\end{array}$ & \\
\hline 2 & Top/senior & Committed to project scope & $87 \%(92)$ \\
\hline & management & & $81 \%(86)$ \\
\hline 3 & Project team members & $\begin{array}{l}\text { Project evaluation measures are very dear to team } \\
\text { members and included from the beginning }\end{array}$ & $73 \%(77)$ \\
\hline 4 & Project manager & Committed to project scope & $72 \%(76)$ \\
\hline 5 & Project team members & Motivated & $72 \%(76)$ \\
\hline 6 & $\begin{array}{l}\text { Strategic link and } \\
\text { company-wide }\end{array}$ & $\begin{array}{l}\text { Sufficient resources are at the disposal of the project } \\
\text { manager/team }\end{array}$ & $72 \%(76)$ \\
\hline 7 & Project manager & Enthusiasm, positive attitude, creative thinking & $71 \%(75)$ \\
\hline 8 & $\begin{array}{l}\text { Social and external } \\
\text { influences }\end{array}$ & $\begin{array}{l}\text { Project creates a feeling of needed change for the } \\
\text { better, change for the future }\end{array}$ & $71 \%$ (75) \\
\hline 9 & $\begin{array}{l}\text { Top/senior } \\
\text { management }\end{array}$ & $\begin{array}{l}\text { Good knowledge and understanding of business and } \\
\text { manufacturing strategies and strategic goals }\end{array}$ & $70 \%(74)$ \\
\hline 10 & Project manager & Strong goal orientation & $69 \%(73)$ \\
\hline 11 & $\begin{array}{l}\text { Strategic link and } \\
\text { company-wide }\end{array}$ & $\begin{array}{l}\text { Key implementation tasks and milestone are } \\
\text { sufficiently defined }\end{array}$ & $68 \%(72)$ \\
\hline 12 & $\begin{array}{l}\text { Project management } \\
\text { processes }\end{array}$ & Project quality management & $68 \%(72)$ \\
\hline 13 & Project manager & Ability to see the project as a whole & $67 \%(71)$ \\
\hline 14 & $\begin{array}{l}\text { Top/senior } \\
\text { management }\end{array}$ & $\begin{array}{l}\text { Provides full, active and clearly visible support to the } \\
\text { project during its whole life }\end{array}$ & $67 \%(71)$ \\
\hline 15 & Top/senior & Involved in strategy formulation & $6870(i 1)$ \\
\hline 16 & $\begin{array}{l}\text { Strategic link and } \\
\text { company-wide }\end{array}$ & $\begin{array}{l}\text { There is a limited number of projects being } \\
\text { implemented in manufacturing at any one time in } \\
\text { order to provide focus and prioritise resources }\end{array}$ & $66 \%(70)$ \\
\hline 17 & Project manager & Organizing skills & $65 \%(69)$ \\
\hline 18 & $\begin{array}{l}\text { Strategic link and } \\
\text { company-wide }\end{array}$ & $\begin{array}{l}\text { All performance measures are linked to strategic } \\
\text { manufacturing objectives and are clearly identified } \\
\text { (results and timescales) }\end{array}$ & $65 \%(69)$ \\
\hline 19 & Project team members & Enthusiasm, positive attitude, creative thinking & $64 \%(68)$ \\
\hline 20 & Project manager & $\begin{array}{l}\text { Good knowledge and understanding of business and } \\
\text { manufacturing strategies and strategic goals }\end{array}$ & $62 \%(66)$ \\
\hline 21 & Project manager & Planning skills & $62 \%(66)$ \\
\hline 22 & $\begin{array}{l}\text { Manufacturing } \\
\text { employees }\end{array}$ & Awareness of the project & $02 \%(00)$ \\
\hline 23 & $\begin{array}{l}\text { Manufacturing } \\
\text { employees }\end{array}$ & $\begin{array}{l}\text { Trained in how to work with the new } \\
\text { practice/system/application/technology, the outcome } \\
\text { and its advantages }\end{array}$ & \\
\hline 24 & Project manager & $\begin{array}{l}\text { Coping with situations: project manager is flexible, } \\
\text { patient, and persistent }\end{array}$ & $60 \%(64)$ \\
\hline 25 & Project team members & Committed to project scope & $59 \%(63)$ \\
\hline 26 & Project team members & Multifunctional members from different departments & $58 \%(62)$ \\
\hline 27 & $\begin{array}{l}\text { Strategic link and } \\
\text { company-wide }\end{array}$ & $\begin{array}{l}\text { Keep project (or project stage duration) as far below } \\
\text { three years as possible (one year is better) }\end{array}$ & $58 \%(62)$ \\
\hline
\end{tabular}

Table IKSFs (continued)

\begin{tabular}{ll}
\hline New material logistic programme & Customer/supplier cost down project \\
\hline Line transfer to other facility & New inventory management system \\
TQM programme & TPM programme \\
Electronic pull system & Stock reduction programme \\
New mechanisation & Vertical integration initiative \\
Product design change for manufacturability & Merge of various business segments \\
New manufacturing location or relocation & Enterprise-wide business system change \\
Outsourcing project & Downsizing manufacturing initiative \\
Lean manufacturing implementation & Lead time reduction to gain greater market share \\
New design to manufacture programme & New ERP software package implementation \\
New manufacturing structure & Supply chain management \\
Product upgrade & Customer demand management \\
Development of new product line & Six Sigma initiative \\
New manufacturing process implementation & Supplier e-business programme \\
Acquisition of new technology & Set up reduction \\
Alternate supplier & 5S manufacturing programme
\end{tabular}

Table II Main types of SMI considered by the respondents 


\begin{tabular}{|c|c|c|}
\hline Pos. & KSFs & Scoring \\
\hline $\begin{array}{l}\text { People } \\
1\end{array}$ & $\begin{array}{l}\text { Project manager is able to listen, understand, and } \\
\text { communicate accurately and constantly }\end{array}$ & $87^{\circ}$ (92) \\
\hline 2 & Top/senior management is committed to project scope & $81 \%(86)$ \\
\hline 3 & $\begin{array}{l}\text { Project evaluation measures are very clear to team } \\
\text { members and included from the beginning }\end{array}$ & $73 \%(77)$ \\
\hline 4 & Project manager is committed to project scope & $72 \%(76)$ \\
\hline 5 & Project team members are highly motivated & $72 \%(76)$ \\
\hline 7 & $\begin{array}{l}\text { Project manager shows enthusiasm, positive attitude, } \\
\text { creative thinking }\end{array}$ & $71 \%(75)$ \\
\hline 9 & $\begin{array}{l}\text { Top/senior management has good knowledge and } \\
\text { understanding of business and manufacturing strategies } \\
\text { and strategic goals }\end{array}$ & \\
\hline 10 & Project manager shows strong goal orientation & $\begin{array}{l}70 \%(74) \\
69 \%(73)\end{array}$ \\
\hline 13 & $\begin{array}{l}\text { Project manager has the ability to see the project as a } \\
\text { whole }\end{array}$ & $67 \%(71)$ \\
\hline 14 & $\begin{array}{l}\text { Top/senior management provides full, active and clearly } \\
\text { visible support to the project during its whole life }\end{array}$ & $67 \%(71)$ \\
\hline 15 & $\begin{array}{l}\text { Top/senior management is involved in strategy } \\
\text { formulation }\end{array}$ & $66 \%(70)$ \\
\hline 17 & Project manager shows organizing skills & $65 \%(69)$ \\
\hline 19 & $\begin{array}{l}\text { Project team members show enthusiasm, positive } \\
\text { attitude, creative thinking }\end{array}$ & $64 \%(68)$ \\
\hline 20 & $\begin{array}{l}\text { Project manager has good knowledge and understanding } \\
\text { of business and manufacturing strategies and strategic } \\
\text { goals }\end{array}$ & $62 \%(66)$ \\
\hline 21 & Project manager shows planning skills & $62 \%(66)$ \\
\hline 22 & Manufacturing employees are aware of the project & $62 \%(66)$ \\
\hline 23 & $\begin{array}{l}\text { Manufacturing employees are trained in how to work } \\
\text { with the new practice/system/application/technology the } \\
\text { outcome and its advantages }\end{array}$ & $61 \%(65)$ \\
\hline 24 & $\begin{array}{l}\text { Project manager is flexible, patient, persistent, and can } \\
\text { cope well with situations }\end{array}$ & $60 \%(64)$ \\
\hline 25 & Project team members are committed to project scope & $59 \%(63)$ \\
\hline 26 & $\begin{array}{l}\text { Project team is formed by multifunctional members from } \\
\text { different departments }\end{array}$ & $58 \%(62)$ \\
\hline 28 & $\begin{array}{l}\text { The same project manager stays during the whole } \\
\text { duration of the strategic implementation }\end{array}$ & $58 \%(61)$ \\
\hline 29 & $\begin{array}{l}\text { Changes in project team members' responsibilities are } \\
\text { clearly defined and understood }\end{array}$ & $58 \%(61)$ \\
\hline 31 & $\begin{array}{l}\text { Project manager is able to release the energies of his } \\
\text { subordinates, project team members, etc. }\end{array}$ & $53 \%(56)$ \\
\hline 32 & $\begin{array}{l}\text { Project manager delegates authority and is able to give } \\
\text { people the opportunity as group members to participate } \\
\text { in making decisions }\end{array}$ & $53 \%(56)$ \\
\hline 34 & $\begin{array}{l}\text { Top/senior management shows enthusiasm, positive } \\
\text { attitude, creative thinking }\end{array}$ & $51 \%(54)$ \\
\hline
\end{tabular}

Table III KSFs by research category

\begin{tabular}{|c|c|c|c|c|}
\hline & $\begin{array}{l}\text { KSFs in the implementation of } \\
\text { strategic decisions (Al-Ghamdi, } \\
\text { 1998) }\end{array}$ & $\begin{array}{l}\text { KSFs to improve the effectiveness } \\
\text { of the project (Clarke, 1999) }\end{array}$ & $\begin{array}{l}\text { KSFs in the implementation of IT } \\
\text { software projects (Hartman and } \\
\text { Ashrafi, 2002) }\end{array}$ & $\begin{array}{l}\text { KSFs in the implementation of ERP } \\
\text { (Umble ef al., 2003) }\end{array}$ \\
\hline 1 & $\begin{array}{l}\text { Communication between all parties } \\
\text { involved in the process of } \\
\text { implementation }\end{array}$ & $\begin{array}{l}\text { Communication throughout the } \\
\text { project }\end{array}$ & $\begin{array}{l}\text { Owner is informed of the project } \\
\text { status and his/her approval is } \\
\text { obtained at each stage }\end{array}$ & $\begin{array}{l}\text { Clear understanding of strategic } \\
\text { goals }\end{array}$ \\
\hline 2 & $\begin{array}{l}\text { Updated information systems in } \\
\text { order to ensure better monitoring of } \\
\text { the implementation activities }\end{array}$ & Clear objectives and scope & $\begin{array}{l}\text { Owner is consulted at all stages of } \\
\text { development and implementation }\end{array}$ & Commitment by top management \\
\hline 3 & $\begin{array}{l}\text { Good control system over quality } \\
\text { and oost involve in the process }\end{array}$ & $\begin{array}{l}\text { Breaking the project into "bite sized } \\
\text { chunks" }\end{array}$ & $\begin{array}{l}\text { Proper communication channels are } \\
\text { established at appropriate levels in } \\
\text { management the project team }\end{array}$ & Excellent project management \\
\hline 4 & & $\begin{array}{l}\text { Using project plans as working } \\
\text { documents }\end{array}$ & $\begin{array}{l}\text { The project has a dearly defined } \\
\text { mission }\end{array}$ & $\begin{array}{l}\text { Organisational change } \\
\text { management }\end{array}$ \\
\hline 5 & & & $\begin{array}{l}\text { Top management is willing to } \\
\text { provide the necessary resources } \\
\text { (money, expertise, equipment) }\end{array}$ & A great implementation team \\
\hline 6 & & & $\begin{array}{l}\text { The project achieves its estimated } \\
\text { business purpose }\end{array}$ & Data accuracy \\
\hline 7 & & & $\begin{array}{l}\text { A detailed project plan (including } \\
\text { time schedules, and milestones) } \\
\text { with a detailed budget in place }\end{array}$ & Extensive education and training \\
\hline 8 & & & $\begin{array}{l}\text { The appropriate technology and } \\
\text { expertise are available }\end{array}$ & Focused performance measures \\
\hline 9 & & & $\begin{array}{l}\text { Project changes are managed } \\
\text { through a formal process }\end{array}$ & Multi-site issues \\
\hline 10 & & & $\begin{array}{l}\text { The project is completed with } \\
\text { minimal and mutually agreed scope } \\
\text { changes }\end{array}$ & \\
\hline
\end{tabular}

Table IV KSFs in selected literature 


\section{References}

APM Association for Project Management (2000), Project Management Body of Knowledge, Dixon, M. (Ed.), The Association for Project Management, High Wycombe.

Al-Ghamdi, S.M. (1998), "Obstacles to successful implementation of strategic decisions: the British experience", European Business Review, Vol. 98 No.6, pp.322-7.

Alexander, L. (1985), "Successfully implementing strategic decisions", Long Range Planning, Vol. 18 No.3, pp.91-7. Baggaley, A.R. (1964), Intermediate Correlation Methods, John Wiley \& Sons, New York, NY.

Baines, T.S., Hamblin, D.J., Harrison, D.K. (1993), "A unified classification of manufacturing strategies and design processes", Engineering Management, Vol. 3 No.6, pp.281-6.

Baker, M.J. (1991), Research for Marketing, Macmillan, London.

Beer, M., Eisentat, R.A., Spector, B. (1990), "Why change programs don't produce change", Harvard Business Review, No.November/December, pp.158-66.

Blackburn, S. (2002), "The project manager and the project-network", International Journal of Project Management, Vol. 20 pp.199-204.

Boote, A.S. (1981), "Reliability of psychographic scales", Journal of Advertisement Research, Vol. 21 No.5, pp.53-60.

Boyd, H.W., Wesfall, R., Stasch, S.F. (1989), Marketing Research: Text and Cases, Irwin, Homewood, IL.

Churchill, G.A., Peter, J.P. (1984), "Research design effect on the reliability of rating", Journal of Marketing Research, No.1, pp.360-75.

Clarke, A. (1999), "A practical use of key success factors to improve the effectiveness of project management", International Journal of Project Management, Vol. 17 No.3, pp.139-45.

Clarke, A., Garside, J. (1997), "The development of a best practice model for change management", European Management Journal, Vol. 15 No.5, pp.537-45.

Cooke-Davies, T. (2002), "The 'real' success factors on projects", International Journal of Project Management, Vol. 20 pp.185-90.

Cronbach, L.J. (1970), "Test validation", in Thorndike, R.L. (Eds),Educational Measurement, 2nd ed., American Council on Education, Washington, DC.

DTI (1988), Competitive Manufacturing: A Practical Approach to the Development of a Manufacturing Strategy, IFS Publications, London.

El-Sabaa, S. (2001), "The skills and career path of an effective project manager", International Journal of Project Management, Vol. 19 pp.1-7.

Fillipini, R., Raffo, J.F. (1990), "Information technology and automation in manufacturing and their impact on corporate strategy", Proceedings of the 5th International Conference of The Operations Management Association (UK), Vol. 1 pp.143-54.

Fitz-Gibbon, C.T., Morris, L.L. (1987), How to Analyze Data, SAGE Publications, Thousand Oaks, CA.

Garvin, D.A. (1993), "Manufacturing strategic planning", California Management Review, Vol. 35 No.4, pp.85-106.

Green, P.E. ,, Tull, D.S., Albaum, G. (1988), Research for Marketing Decisions, Prentice-Hall, Englewood Cliffs, NJ. 
Grover, V., Jeong, S.R., Kettinger, W.J., Teng, J.T.C. (1995), "The implementation of business process reengineering", Journal of Management Information Systems, Vol. 12 pp.109-44.

Grundy, T. (1998), "Strategy implementation and project management", International Journal of Project Management, Vol. 16 No.1, pp.43-50.

Gunn, T.G. (1987), Manufacturing for Competitive Advantage: Becoming a World Class Manufacturer, Ballinger Publishing Company, Boston, MA.

Hartman, F., Ashrafi, R.A. (2002), "Project management in the information systems and information technologies industries", Project Management Journal, Vol. 33 No.3, pp.5-15.

Hauc, A., Kovac, J. (2000), "Project management in strategy implementation - experiences in Slovenia", International Journal of Project Management, Vol. 18 pp.61-7.

Hayes, R.H., Wheelwright, S.C. (1984), Restoring Our Competitive Edge: Competing through Manufacturing, John Wiley \& Sons, Inc., New York, NY.

Hunt, S.D., Sparkman, R.D., Wilcox, J.B. (1982), "The pretest in survey research: issues and preliminary findings", Journal of Marketing Research, No.19, pp.265-75.

Kinnear, T., Taylor, J. (1996), Marketing Research: Applied Approach, McGraw-Hill, New York, NY.

Kotha, S., Swamidass, P.M. (2000), "Strategy, advanced manufacturing technology and performance: empirical evidence", Journal of Operations Management, Vol. 18 No.3, pp.257-77.

Likert, R. (1932a), "A technique for the measurement of attitudes", Archives of Psychology, No.140.

Likert, R. (1967), "The method of constructing an attitude scale", in Fishbein, M. (Eds), Readings in Attitude Theory and Measurement, John Wiley, New York, NY, pp.90-5.

Malhotra, N.K. (1993), Marketing Research: An Applied Orientation, Prentice-Hall International, London.

Marucheck, A., Pannesi, R., Anderson, C. (1990), "An exploratory study of the manufacturing strategy process in practice", Journal of Operations Management, Vol. 9 No.1, pp.101-23.

Maylor, H. (2001), "Beyond the Gantt chart: project management moving on", European Management Journal, Vol. 19 No.1, pp.92-100.

Maylor, H. (2003), Project Management, 3rd ed., Prentice-Hall/Pearson Education, London.

Mikkelsen, H., Olsen, W., Riis, J.O. (1991), "Management of internal projects", International Journal of Project Management, Vol. 9 No.2, pp.77-81.

Milis, K., Mercken, R. (2002), "Success factors regarding the implementation of ICT investment projects", International Journal of Production Economics, Vol. 80 pp.105-17.

Miller, S.S. (1988), Competitive Manufacturing: Using Productions as a Management Tool, Van Nostrand Reinhold, Wokingham.

O'Neill, P., Sohal, A.S. (1999), "Business process reengineering: a review of recent literature", Technovation, Vol. 19 pp.571-81.

Oppenheim, A.N. (1996), Questionnaire Design, Interviewing and Attitude Measurement, Pinter Publishers, London and New York, NY. 
PMI Standards Committee (2000), A Guide to the Project Management Body of Knowledge, Project Management Institute, Philadelphia, PA.

Papke-Shields, K.E., Malhotra, M.K. (2001), "Assessing the impact of the manufacturing executive's role on business performance through strategic alignment", Journal of Operations Management, Vol. 19 pp.5-22.

Pellegrinelli, S., Bowman, C. (1994), "Implementing strategy through projects", Long Range Planning, Vol. 27 No.4, pp.125-32.

Pinto, J.K. (2000), "Understanding the role of politics in successful project management", International Journal of Project Management, Vol. 18 pp.85-91.

Platts, K.W. (1990), "Manufacturing audit in the process of strategy formulation", PhD dissertation, University of Cambridge, Cambridge.

Sashittal, H.C., Wilemon, D. (1996), "Marketing implementation in small and midsized industrial firms", Industrial Marketing Management, No.25, pp.67-78.

Skinner, W. (1969), "Manufacturing - missing link in corporate strategy", Harvard Business Review, pp.136-45.

Turner, J.R. (1993), The Handbook of Project-Based Management, McGraw-Hill, Maidenhead.

Umble, E.J., Haft, R.R., Umble, M.M. (2003), "Enterprise resource planning: implementation procedures and critical success factors", European Journal of Operational Research, Vol. 146 pp.241-57.

Van Der Merwe, A.P. (2002), "Project management and business development: integrating strategy, structure, processes and projects", International Journal of Project Management, Vol. 20 pp.401-11.

Webb, J.R. (1992), Understanding and Designing Marketing Research, Academic Press, London.

Weisberg, H.F., Bowen, B.D. (1977), An Introduction to Survey Research and Data Analysis, W.H. Freeman and Company, London.

White, D., Fortune, J. (2002), "Current practice in project management - an empirical study", International Journal of Project Management, Vol. 20 pp.1-11.

Zairi, M., Sinclair, D. (1995), "Business process engineering and process management: a survey of current practice and future trends in integrated management", Management Decision, Vol. 33 No.3, pp.3-16.

Zikmund, W.G. (1997), Business Research Methods, The Dryden Press, Fort Worth, TX. 


\section{Appendix. Factors included in the questionnaire and the relevant references that suggest them}

\section{Project manager}

(1) Good knowledge and understanding of business and manufacturing strategies and strategic goals (Umble et al., 2003; Pellegrinelli and Bowman, 1994). (2) Involved in manufacturing strategy formulation (Blackburn, 2002; PapkeShields and Malhotra, 2001; Al-Ghamdi, 1998). (3) Trained in project management (Pellegrinelli and Bowman, 1994; Milis and Mercken, 2002; Hartman and Ashrafi, 2002; Maylor, 2001; Clarke, 1999). (4) Committed to project scope (Clarke, 1999). (5) "Project manager" is a position in the organisational structure of the company (Pellegrinelli and Bowman, 1994). (6) The project manager is assigned to the SMI project on a FULL TIME basis (Pellegrinelli and Bowman, 1994). (7) Experience with similar projects (Milis and Mercken, 2002). (8) Project manager is able to release the energies of his subordinates, project team members, etc. (El-Sabaa, 2001). (9) Communication: project manager is able to listen, understand, and communicate accurately and constantly (El-Sabaa, 2001; Clarke, 1999; Milis and Mercken, 2002). (10) Coping with situations: project manager is flexible, patient, and persistent (El-Sabaa, 2001; Milis and Mercken, 2002). (11) Delegatinffect manager is able to give people the opportunity as group members to participate in making decisions (El-Sabaa, 2001; Maylor, 2001; Milis and Mercken, 2002). (12) Political sensitivity: project manager perceives and recognises the attitudes of his superiors, equals, or subordinates and he accordingly behaves (El-Sabaa, 2001; Pinto, 2000). (13) High self-esteem (El-Sabaa, 2001). (14) Enthusiasm, positive attitude, creative thinking (El-Sabaa, 2001; Milis and Mercken, 2002). (15) Planning skills (El-Sabaa, 2001). (16) Organizing skills (El-Sabaa, 2001). (17) Strong goal orientation (El-Sabaa, 2001). (18) Ability to see the project as a whole (El-Sabaa, 2001). (19) Ability to visualize the relationship of the project to the industry and the community (ElSabaa, 2001; Clarke, 1999). (20) Strong problem solving orientation (El-Sabaa, 2001). (21) Special knowledge in the use of analysis tools and techniques (El-Sabaa, 2001; Clarke and Garside, 1997). (22) Knowledge and understanding of manufacturing operations (El-Sabaa, 2001). (23) Understanding of organisational methods, processes, procedures and policies (El-Sabaa, 2001). (24) Experience or knowledge of the technology required and the subject matter of the project (El-Sabaa, 2001). (25) Skills in the use of computers (El-Sabaa, 2001; Milis and Mercken, 2002). (26) Skills in finance and accounting (PMI Standards Committee, 2000). (27) High level of authority (Pinto, 2000). (28) Empowered, rapid decision making (Pinto, 2000). (29) High knowledge of the company (functions, departments, hierarchy, people). (30) Negotiation and Persuasion skills (Pinto, 2000). (31) Keeps accurate records of every action/decision. (32) Personal reward system (Marucheck et al., 1990). (33) Clear career path after project completion (El-Sabaa, 2001). (34) The same project manager stays during the whole duration of the strategic implementation (Al-Ghamdi, 1998).

\section{Top/senior management}

(35) Good knowledge and understanding of business and manufacturing strategies and strategic goals (Umble et al., 2003; Van Der Merwe, 2002; Pellegrinelli and Bowman, 1994). (36) Involved in strategy formulation (Papke-Shields and Malhotra, 2001; Al-Ghamdi, 1998). (37) Trained in project management (Hartman and Ashrafi, 2002; Van Der Merwe, 2002; Maylor, 2001; Clarke, 1999). (38) Committed to project scope (Umble et al., 2003; Van Der Merwe, 2002; Clarke, 1999; Clarke and Garside, 1997). (39) Provides full, active and clearly visible support to the project during its whole life (Pellegrinelli and Bowman, 1994; Milis and Mercken, 2002; Marucheck et al., 1990; Hartman and Ashrafi, 2002). (40) Trained in how to be good project clients (Pellegrinelli and Bowman, 1994; Van Der Merwe, 2002). (41) There is an executive management planning committee or project steering group formed by top/senior management (Pellegrinelli and Bowman, 1994; Umble et al., 2003; Clarke and Garside, 1997). (42) Enthusiasm, positive attitude, creative thinking (Milis and Mercken, 2002; Marucheck et al., 1990). (43) Bypass existing systems, structures and hierarchies in favour of successful strategy implementation (Pellegrinelli and Bowman, 1994; Marucheck et al., 1990). (44) The same top/senior management stays during the whole duration of the strategic implementation (Al-Ghamdi, 1998). 


\section{Project team members}

(45) Good knowledge and understanding of business and manufacturing strategies and strategic goals (Umble et al., 2003; Milis and Mercken, 2002). (46) Involved in strategy formulation (Papke-Shields and Malhotra, 2001; AlGhamdi, 1998). (47) Trained in project management (Hartman and Ashrafi, 2002; Garvin, 1993; Clarke, 1999). (48) Committed to project scope (Marucheck et al., 1990; Clarke, 1999; Milis and Mercken, 2002). (49) Empowered, rapid decision making (Maylor, 2001). (50) Project evaluation measures are very clear to team members and included from the beginning (Hartman and Ashrafi, 2002; Milis and Mercken, 2002; Clarke, 1999). (51) Individual reward system (Marucheck et al., 1990; Milis and Mercken, 2002; Maylor, 2001). (52) When team goals are reached, rewards should be presented in a very visible way (Milis and Mercken, 2002). (53) Changes in responsibilities are clearly defined and understood (Marucheck et al., 1990). (54) Full time members (Pinto, 2000). (55) Multifunctional members from different departments (Pinto, 2000; Van Der Merwe, 2002; Milis and Mercken, 2002). (56) If someone is unable to achieve agreed-upon objectives, they should either receive the needed assistance or be replaced. (57) Team is composed of top-notch people who are chosen for their skills, past accomplishments, reputation, and flexibility (Umble et al., 2003). (58) Project team members keep accurate records of every action/decision. (59) Stability: new major departmental/functional/non-project-related responsibilities are not created during project life (Milis and Mercken, 2002). (60) Enthusiasm, positive attitude, creative thinking (Milis and Mercken, 2002). (61) Motivated (Milis and Mercken, 2002; Clarke, 1999). (62) Good relationship among project team members (Milis and Mercken, 2002). (63) The same project team members stay during the whole duration of the strategic implementation (AlGhamdi, 1998).

\section{Manufacturing employees (non project team members but affected by the project)}

(64) Good knowledge and understanding of business and manufacturing strategies and strategic goals (Umble et al., 2003; Marucheck et al., 1990). (65) Involved in strategy formulation (Papke-Shields and Malhotra, 2001; Al-Ghamdi, 1998). (66) Trained in project management (Hartman and Ashrafi, 2002; Clarke, 1999). (67) Committed to project scope (Al-Ghamdi, 1998; Clarke, 1999). (68) Awareness of the project (Al-Ghamdi, 1998; Marucheck et al., 1990; Clarke, 1999). (69) Understanding of project scope (Al-Ghamdi, 1998; Clarke, 1999). (70) Trained in how to work with the new practice/system/application/technology, the outcome and its advantages (Milis and Mercken, 2002; Marucheck et al., 1990). (71) Involved in project development and execution (constrained by the nature of the project) (Marucheck et al., 1990). (72) Enthusiasm, positive attitude, creative thinking (Milis and Mercken, 2002).

\section{Strategic link and company-wide}

(73) SMI project(s) implementation is considered in the process of development and formulation of strategy (Hauc and Kovac, 2000; Papke-Shields and Malhotra, 2001; Al-Ghamdi, 1998). (74) The organisation engages in excellent project management including clear scope definition, resource planning, project progress tracking system, and business processes change management (Umble et al., 2003; Hartman and Ashrafi, 2002; Van Der Merwe, 2002; Pellegrinelli and Bowman, 1994). (75) Organisational change management techniques are utilised (people, structures, skills, etc.) (Umble et al., 2003; Milis and Mercken, 2002; Hartman and Ashrafi, 2002). (76) Portfolio and programme management practices are used and allow the enterprise to resource fully a suite of projects that are thoughtfully and dynamically matched to the corporate strategy and business objectives (Cooke-Davies, 2002; Marucheck et al., 1990; Maylor, 2001). (77) A sense of urgency is maintained during the life of the project (CookeDavies, 2002). (78) All performance measures are linked to strategic manufacturing objectives and are clearly identified (results and timescales) (Cooke-Davies, 2002; Hartman and Ashrafi, 2002; Clarke, 1999). (79) Key implementation tasks and milestones are sufficiently defined (Hartman and Ashrafi, 2002; Clarke, 1999). (80) The "financial unit of analysis or cost/benefit analysis" of sub-projects is extended to cover the wider effect of the complete SMI implementation project (Grundy, 1998). (81) Information systems used to monitor implementation at all levels are adequate (Al-Ghamdi, 1998; Clarke, 1999). (82) The integrity of the performance measurement baseline is maintained (Cooke-Davies, 2002). (83) The time span for project completion is flexible if new or continuous improvement initiatives are generated during the process (Cooke-Davies, 2002). (84) Keep project (or project stage duration) as far below three years as possible (one year is better) (Cooke-Davies, 2002; Marucheck et al., 1990; 
Garvin, 1993). (85) Adequacy of company-wide education on the concepts of risk management (Cooke-Davies, 2002; Hartman and Ashrafi, 2002). (86) Maturity of the organisation's processes for assigning ownership of risks (CookeDavies, 2002; Hartman and Ashrafi, 2002). (87) There is an effective benefits delivery and management process that involves the mutual co-operation of project management and line management functions (Cooke-Davies, 2002; Marucheck et al., 1990). (88) There is an effective means of "learning from experience" on projects in a way that encourages continuous improvement of project management processes and practices (Cooke-Davies, 2002; Pellegrinelli and Bowman, 1994; Maylor, 2001; Clarke, 1999). (89) SMI project(s) is defined rigorously, but at the same time there is some latitude in terms of fluidity of scope and focus within the project definition (Grundy, 1998; Maylor, 2001; Pellegrinelli and Bowman, 1994). (90) There is a limited number of projects being implemented in manufacturing at any one time in order to provide focus and prioritise resources (Maylor, 2001; Garvin, 1993; Clarke, 1999). (91) Sufficient resources are at the disposal of the project manager/team (Milis and Mercken, 2002; Marucheck et al., 1990; Maylor, 2001; Clarke, 1999). (92) Competing or departmental activities don't distract attention from implementing the strategic initiative (Al-Ghamdi, 1998; Maylor, 2001). (93) Supportive structures are in place to help individuals access easily what they need for facilitating the implementation process (Al-Ghamdi, 1998; Marucheck et al., 1990; Maylor, 2001).

Social and external influences (Milis and Mercken, 2002; Al-Ghamdi, 1998; Alexander, 1985) (94) SMI project(s) is launched during a good situation for the national economy and the industry in general (macroeconomics). (95) SMI project(s) is launched during a good financial situation for the specific company (microeconomics). (96) Consideration is given to sensitive workforce issues. (97) Project creates a feeling of needed change for the better, change for the future.

\section{Project management processes}

(98) Project integration management: processes required to ensure that the various elements of the project are properly coordinated (PMI Standards Committee, 2000). (99) Project scope management: processes required to ensure that the project includes all the work required, and only the work required, to complete the project successfully (PMI Standards Committee, 2000). (100) Project time management: processes required to ensure timely completion of the project (PMI Standards Committee, 2000). (101) Project cost management: processes required to ensure that the project is completed within the approved budget (PMI Standards Committee, 2000). (102) Project quality management: processes required to ensure that the project will satisfy the needs for which it was undertaken (PMI Standards Committee, 2000). (103) Project human resource management: processes required to make the most effective use of the people involved with the project (PMI Standards Committee, 2000). (104) Project communications management: processes required to ensure timely and appropriate generation, collection, dissemination, storage, and ultimate disposition of project information (PMI Standards Committee, 2000; Clarke, 1999). (105) Project risk management: processes concerned with identifying, analysing, and responding to project risk (PMI Standards Committee, 2000; Hartman and Ashrafi, 2002; Cooke-Davies, 2002). (106) Project procurement management: processes required to acquire goods and services from outside the performing organisation (PMI Standards Committee, 2000). (Enrique Minarro-Viseras is an Engineering Doctorate Research Student in the Manufacturing Systems Department of the School of Industrial and Manufacturing Science at Cranfield University, England, and an Engineering Manager for a multinational electronics company. He has an Engineering degree from the Universidad Politécnica de Valencia, Spain, and holds an MSc from Cranfield. His research interests include manufacturing strategy implementation and project management. He can be reached the School of Industrial and Manufacturing Science, Cranfield University, Cranfield, Bedford, MK43 OAL, United Kingdom. E-mail: e.minarroviseras.1999@cranfield.ac.uk 